\title{
Correction to: An evaluation of the formalised AcciMap approach for accident analysis in healthcare
}

\author{
Oseghale Osezua Igene ${ }^{1}\left[\right.$ (D) Christopher W. Johnson ${ }^{2} \cdot$ Jenny Long ${ }^{3}$
}

Published online: 27 March 2021

(c) Springer-Verlag London Ltd., part of Springer Nature 2021

\section{Correction to: Cognition, Technology and Work https://doi.org/10.1007/s10111-021-00669-w}

In the original article, the corresponding author Igene Oseghale Osezua was affiliated incorrectly.

The correct affiliation is Igene Oseghale Osezua, School of Computing Science, University of Glasgow, G12 8RZ, Glasgow, United Kingdom.

The original article has been corrected.

Publisher's Note Springer Nature remains neutral with regard to jurisdictional claims in published maps and institutional affiliations.

The original article can be found online at https://doi.org/10.1007/ s10111-021-00669-w.

Oseghale Osezua Igene

o.igene.1@ research.gla.ac.uk

Christopher W. Johnson

c.w.johnson@qub.ac.uk

Jenny Long

jennifer.long1@nhs.net

1 School of Computing Science, University of Glasgow, Glasgow G12 8RZ, Scotland, United Kingdom

2 Faculty of Engineering and Physical Sciences, Queen's University Belfast, Belfast BT9 5BN, Northern Ireland, United Kingdom

3 Unscheduled Care Improvement, National Health Service Lothian, Edinburgh EH1 2EA, Scotland, United Kingdom 